\title{
Ozone as a disinfectant in the food industry
}

Dobeic ${ }^{1}, M$.

Review

\section{SUMMARY}

In the food processing industry disinfectants should ensure the quality and microbiological safety of food without the risks for the human health or environment. One of the potential and alternative less toxic disinfectants is the ozone. It is highly effective and environmentally acceptable disinfectant applicable on several places of food production premises, e.g. on equipment and directly on food products.

Key words: ozone, food industry, sanitation, disinfection

\section{INTRODUCTION}

In the food industry ozone is one of the potential and alternative less toxic disinfectants (O'Donnell et al., 2012; Wysok et al., 2006; Guzel-Seydim1 et al., 2004). Ozone is highly effective microbicide agent on the broadspectrum of microorganisms including Gram-positive and Gram-negative bacteria, fungi, viruses, protozoa and spores (Pascual et al., 2007; Guzel-Seydim et al., 2004; Restaino et al., 1995). The mechanizms of ozone in inactivation of microorganisms are numerous, while ozone acts on the constituents of cell membrane and on the cellular structure as on enzymes and genetic material (Pascual et al., 2007). While ozone, after it decomposes back into oxygen molecula, does not leave practically any residue in the environment it is an important alternative to mainly used chlorine disinfectants in the food industry (Pascual et al., 2007; Kim et al., 2003; Wei et al., 2007). In comparison with chlorine disinfectants, ozone is more effective against microorganisms (Wysok et al. 2006). The microbicidal operation of ozone is not reduced even in low temperature working solutions, what is important contribution to energy saving and since ozone is produced on site, the transport and storage drop out (Wei et al., 2007; Moore et al.; 2000, Wysok et al.; 2006). Due to the special oxidative mechanisms on microorganisms ozone does not generate their resistance while it destroy microorganisms instantly (Rice et al., 2002; Kim et al., 2003).

\section{What is ozone?}

Ozone is a naturally formed gas generated in the stratosphere $(15-50 \mathrm{~km}$ altitude) as a result of UV and solar radiation $(<240 \mathrm{~nm})$ of oxygen (Yousef et al., 2001). It can be produced synthetically in photochemical processes, from UV radiation, high-voltage electric arc, and the gamma radiation (Mustafa, 1990; Green et al., 2012). Ozone is allotropic form of oxygen resulting from the fusion of free radicals of oxygen in the molecular oxygen, forming ozone as triatomic molecule (O3) (Kim et al., 2003). Ozone is generating form oxygen molecules when they are exposed to a source of high energy such as electrical current at high voltages, or ultraviolet radiation. Oxygen

1 Martin Dobeic. PhD, associated professor, University of Ljubljana, Veterinary Faculty, Institute for Food Safety, Feed and Environment, Department for Environment and Animal Nutrition, Welfare and Hygiene, Gerbičeva 60, SI-1000 Ljubljana, Slovenia; 
molecules divide into the free oxygen atoms which react with the remaining of oxygen molecules into the triatomic ozone molecules (O3) (Green et al., 2012) (Figure 1.).

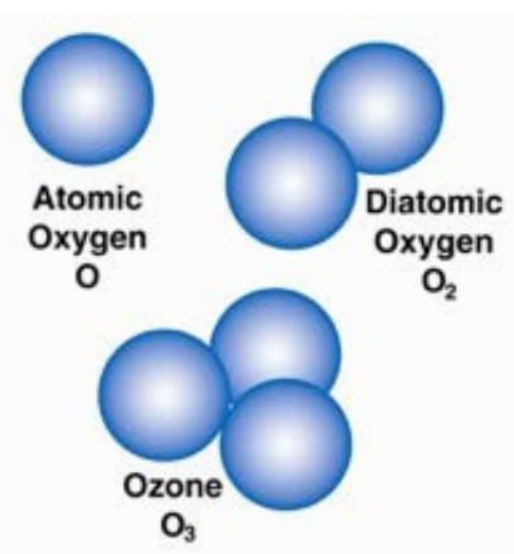

Figure 1 Molecular structure of ozone (Bollinger, 2013)

Ozone as a gas have a characteristic odor described as odor of fresh air after storms, named from the Greek word "Ozein", which means "to smell" (Green et al., 2012; Weschler, 2000). As a gas ozone has lower relative density than the air, blue in the high concentrations, meanwhile at low concentrations ozone is a colorless gas. Chemichally ozone is unstable gas with short half-life in the air, still it is partly soluble in water with relatively long half-life at normal temperatures and pressures (Rice, 1986; Green et al. 2012; Muthukumarappan et al., 2000; Mahapatra et al., 2005; Roth et al., 1981). For instance the general opinion is that the half-life of ozone dissolved in distilled water at $20^{\circ} \mathrm{C}$ is about 20 to 30 minutes (Khadre et al., 2001). Ozone solubility depends on the $\mathrm{pH}$ of water and is more soluble in colder waters at a pH below 7.0, moreover if the $\mathrm{pH}$ increases, ozone rapidly decompose in reactive free radicals, such as hydroxyl ions (Pehkonen, 2001; Green et al., 2012; Battino et al., 1983; Forni et al., 1982); however in both environments ozone decomposes into hydroxyl radicals, oxygen and hydroxide ions intensively (Pehkonen, 2001; Green et al., 2012; Gordon, 1995; Wysok et al., 2006; Staehelin et al., 1982; Sehested et al., 1992; Forni et al., 1982). In aqueous solutions stability of ozone is dependent on the content of organic substances which accelerate ozone decomposition (Wysok et al., 2006; Hewes et al., 1971). While ozone is decomposing with contemporary production of hydroxyl free radicals, oxygen and hydroxide ions, this chemical reactions are responsible for highly efficient oxidation wherein ozone has the relatively high electrochemical oxidation potential $(E=2.07$ V), what explain why ozone is one of the most powerful disinfectants with contemporary characteristic of inducing low, or none by-products as opposed to the use of chlorine disinfectants (Pascual et al., 2007; Martinez-Huitle and Ferro, 2006; Lopez-Galvez et al., 2012).

\section{Production of ozone}

Ozone can be produced synthetically by one of the three processes: the process of electrical (corona) discharge, the electrochemical method, and ultraviolet (UV) radiation. The most used method is electrical (corona) discharge. In this process relatively low ozone production is achieved consuming a lot of electricity meanwhile electrochemical and UV metods are even less effective (Tapp and Rice, 2012; Šimek et al., 2012; Mahapatra et al., 2005; Anonymous, 1983).

\section{The process of electrical (corona) discharge}

This is the method in which the properly cleaned dried air, or pure oxygen $(\mathrm{O} 2)$ is streaming between the two high voltage electrodes separated by a dielectric material (Mahapatra et al., 2005; Langlais et al., 1991, cited by Tapp and Rice, 2012). The electricity at a voltage of $5000 \mathrm{~V}$ is needed, inducing extra high heat, which, if cooling of electrodes is not provided, can cause a rapid reversal decomposition of ozone into oxygen atoms and molecules, especially when the temperatures raise above $35^{\circ} \mathrm{C}$ (Mahapatra et al., 2005; Lukes et al., 2005; Chang et al., 1991). When the ozone is generated from the dry air, the mixture of ozone and the rest of the air usually contains 1 to $3 \%$ ozone, and 3 to $6 \%$ ozone when pure oxygen for ozone generation is used (Muthukumarappan et al., 2000; Mahapatra et al., 2005).

\section{Electrochemical (cold plasma) method}

In this method electric current is passing between the anode and the cathode in the electrolytic solution of water and electro anions. The result of this process is the generation of ozone and oxygen molecules at the anode. No supply of gas and low-voltage of electro current is needed, thus the gas supply is unnecessary and electric energy demands are low (Mahapatra et al., 2005; Pekarek et al., 2003).

\section{Ultraviolet (UV) method}

The energy of UV radiation (140-190nm wavelength) split the molecules of oxygen or pure oxygen (O2) into the oxygen atoms which react with the rest of oxygen molecules into ozone. Low amounts of ozone are achieved by this method (Muthukumarappan et al., 2000; Mahapatra et al., 2005).

\section{MECHANISM OF ANTIMICROBIAL ACTION OF OZONE}

Ozone is effective on the very wide range of microorganisms at relatively low concentrations (Khadre et al., 2001; 
Foegeding et al., 1985; Young et al., 2004), including viruses since it acts on the polypeptides in viral envelopes and on the RNA (Guzel-Seydim et al., 2004; Kim et al., 1999). In addition the ozone can also decompose reactive components of the biofilm (Green et al., 1993; Pascual et al., 2007).

Among the other ozone is efficient against Listeria monocytogenes, Staphylococcus aureus,, Enterococcus faecalis, Salmonella typhimurium., Escherichia coli, Pseudomonas aeruginosa and Yersinia enterocolitica, yeasts Candida albicans, Zygosaccharomyces and the spores of Aspergillus niger (Restaino et al., 1995). Ozone also destroys a wide range of viruses and is more effective against enveloped viruses (e.g. vesicular stomatitis virus, Influenza $A$ virus (WSN strain), infectious bovine rhinotracheitis virus) as a non-enveloped viruses (e.g. polio I and infectious hepatitis dog) (Bolton et al., 1982, cited by Green et al., 2012; Guzel-Seydim et al., 2004). Ozone is efficient also against protozoa oocysts of Cryptosporidium parvum (Peeters et al., 1989; Korich et al., 1990).

One of the main microbicide action of ozone is high oxidative reactivity. As a gas or in aqueous solutions ozone decomposes into the free radicals as hydroxyl (HO0), hydroperoxy (.HO2) and superoxide radicals (.O2-) which can destroy microorganisms in several ways (Green et al., 2012). Still it is not clarified which function among the molecular ozone or its decomposition products has the major impact on microorganisms (Pascual et al., 2007; Kim et al., 2003). The microbicidal mechanisms of ozone onto microbial cells is resulting on the effects of the cell enzymes oxidising their double bonds, degradation of membrane glycoproteins and glycolipids (Guzel Seydim et al., 2004), membrane bound enzymes (Murray et al., 1965, cited by Green et al., 2012) , their amino acids and sulfhydryl groups, degradation of proteins and peptides to smaller peptides, oxidising of polyunsaturated acids into acidic peroxides and potential destroying of DNA (Komanapalli and Lau, 1996; Victorin et al., 1992; Green et al., 2012).

Since the ozone has electrophilic properties, while its free radicals are intending to be electrically balanced with unbalanced electrical charged material, resulting in very high oxidation-reduction potential, the basis for the antibacterial action of ozone is oxidation (Beltran 2004, cited by Green et al., 2012). Nevertheless its microbicidal activity is largely dependent on concentration and properties of media where is used. This means the temperature, humidity, $\mathrm{pH}$, and the presence of organic and inorganic substances leftover as the dirt remaining, sanitisers, different additives, such as acids, surfactants, and sugars, can significantly reduce the ozone concentration, at the same time the ozone stability is depending to the type of ozone generation as well (O'Donnell et al., 2012; Graham, 1997; Gordon, 1995; Wysok et al.,
2006; Pascual et al., 2007; Mahapatra et al.,2005; Kim et al., 1999; Kim et al., 2000; Rodriguez-Romo et al. 2005; Khadre et al., 2001).

Thus the microbicide effectiveness of relative instable ozone depends on the residual ozone in treated environment. Residual ozone is presented as the concentration of remaining ozone after the application (Venosa, 1972, cited by Kim et al., 2000). For example clean drinking water has low content of organic or inorganic matter which not significantly influence on the decomposition of ozone, thus remaining of ozone is high, while the other "soiled " environments, with lot of impurities, react with the ozone and decompose it, that is why remaining of ozone is low. Moreover decomposition of ozone is also depending on the type of impurity (Portjanskaja, 2006). The other influencing factor on ozone stability is the temperature of media. The solubility and stability of the ozone in water is higher at lower temperatures what increases its biocidal efficacy (Pascual et al., 2007). That is why the solubility, stability and reactivity of ozone should be adjusted getting the optimal microbicidal efficiency of ozone (Pascual et al., 2007).

\section{THE OZONE AS DISINFECTANT IN FOOD PROCESSING INDUSTRY}

Ozone is an effective disinfectant for disinfection of food production facilities and equipment (Figure 2.). In the

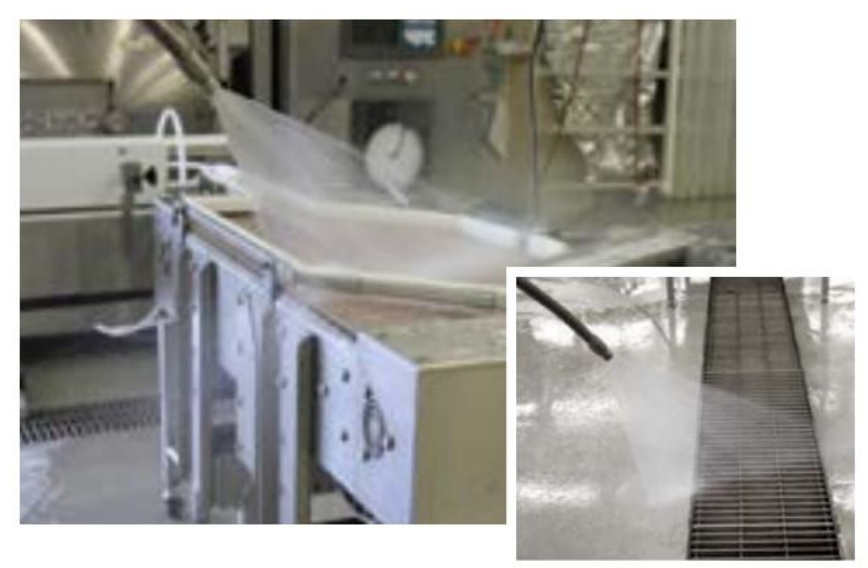

Figure 2 Ozone and surface disinfection in the food industry (DEL Ozone, 2017)

food industry ozonated water is one of the alternative sanitisers and disinfectants. Ozone as ozonated water can be used in cold suspesions, between 15 and $30^{\circ} \mathrm{C}$, what is convenient regarding the energy saving. Moreover the operation of the ozone is faster than other disinfectants, since reaction between the ozone and the contaminated surfaces takes only a few seconds. Furthemore ozone causes protein and fats coagulation what is very convenient from the view of sanitation rinsing efficiency, and at least since ozone did not leave significant residua the 
pollution of the environment is very moderate (Wysok et al., 2006; Kim et al., 1999). Generally speaking ozone as a disinfectant do not leave any residue. Still if ozone react with organic compounds in different environments where is used as a disinfectant, it can degradate to some non-health hazardous by-products, such as aldehydes, ketones, or carboxylic acid (Pascual et al., 2007).

The microbiocidal effectiveness of ozone is used also in food packaging through the plasma decontamination of sealed packages which reduce the number of Escherichia coli and Campylobacter on chicken breasts up to $4,3 \log$ (99,995\% reduction) (Potts et al., 2011).

Ozone can be also used for odour control. The presence of gaseous ozone in concentrations from 0.01 to $0.04 \mathrm{mg} / \mathrm{m} 3$ of air in the cold storage of foods increases the freshness of air (Wysok et al., 2006).

Owing to microbicidal and non toxic properties ozone can be potentially used directly on the food and food contact surfaces. When ozone is used on food directly in proper conditions and concentrations, normally does not modify the significant sensory properties of the food, e.g. it may change some sensory qualities on meat or milk powder due to lipids oxidation (Ipsen, 1989; Mahapatra et al., 2005; Pirani et al., 2010). For example ozone can be used for disinfecting of poultry carcasses in the slaughterhouses (Yang and Chen, 1979; Kim et al., 1999). No side effects e.g. significant impacts on lipid oxidation, loss of skin color on poultry carcasses, were noticed when ozone was used directly on poultry carcasses (Sheldon and Brown, 1986). When ozone is used on food directly, sensory changes of food, happen mostly if too large concentrations of ozone are used for decontamination. Irrespective to this, the influence of ozone on the discoloration and unwanted odors of ozone-treated meat was detected (Foumaud and Lauret, 1972; Mahapatra et al., 2005).

Therefore ozone can be used for disinfection of surfaces, packaging materials, equipment and decontamination of processing water instead of chlorine agents. Namely in the food industry most frequently potentially carcinogenic, harmful and irritating chlorine agents are used for the disinfection (Guzel-Seydim et al., 2004; Olmez et al., 2009). If the ozonation is combined with the addition or in combination with other "environmentally friendly" chemical (e.g. hydrogen peroxide) or physical (e.g. UV radiation) agents, the antimicrobial effectiveness of the ozone can even increased (Kim et al., 2003).

\section{Microbial inactivation}

Restaino et al., (1995) reported about the use of ozonated water and the reduction of more than 5 log units of Salmonella typhimurium and Escherichia coli, more than $4.5 \log$ units of Candida albicans and Zygosaccha- romyces and 1 log unit of Aspergillus niger spores after a 5-min exposure to ozonated water in laboratory conditions. The efficacy of ozone on the inactivation of Listeria monocytogenes was investigated in smoked ham, whereby the significant reduction (about $90 \%$ ) of microorganisms at a concentration of ozone in the range of 0.5-1.0 ppm, in the time of 1-15 minutes and at a temperature of $20^{\circ} \mathrm{C}$ was established (Kaothien et al., 2001; Mahapatra et al., 2005) .

As reported by Loretz et al. (2010) in a study of Fabrizio et al. (2002) the spraying of poultry carcasses with ozonated water $(0.3 \mathrm{~min})$ and cooling with the immersion of poultry carcasses in ozonated water ( $45 \mathrm{~min}$ ) lowered the number of Escherichia coli and Salmonella. typhimurium to $0.4-0.6$ and $0.7-0.9$ log cfu $\mathrm{ml}-1$, respectively .

The use of gaseous ozone and packaging gassing to control the population of Salmonella infantis and Pseudomonas aeruginosa on the skin of chicken carcasses was investigated as well. The reduction in the number of Salmonella was $97 \%$ and $95 \%$ of Pseudomonas. After the treatment with gaseous ozone no sensory changes on were observedon the skin of chicken carcasses (AlHaddad Khawla et al., 2005).

Even the ozone is effective on food spoilage microorganisms (Pseudomonas aeruginosa and Zygosaccharomyces. bailii), fecal contaminants (Escherichia. coli and Enterococcus faecalis), and pathogens (Listeria monocytogenes, Bacillus cereus, Salmonella typhimurium), there are certain restrictions about the use of ozone and its reactions with organic matter (Restaino et al., 1995). Namely ozone first react and oxidise the food substrate before residual ozone kill microorganisms what require a higher concentration and longer exposure of ozone, which could change the properties of foods (Moore et al., 2000). Owing to that simultaneous use of multiple methods with additional or synergistic activity against pathogens is recommended. For example, the treatment of the beef with the ozone and the subsequent heat, or the treatment of shell eggs with ozone and UV radiation (Kim et al., 2003).

Namely ozone was experimentally performed on decontamination of shell eggs (Kamotani et al., 2010; Yuceer et al., 2016). Ozone processing of shell eggs is a new technology with potentially fewer side effects such as heat pasteurization of eggs. Inactivation of SalmoneIla enteritidis on shell eggs treated with ozone and UV radiation was investigated. The results showed that treatment of shell eggs with gaseous ozone or UV, separately or in combination, significantly reduced Salmonella counts (Rodriguez-Romo et al., 2005). There were no adverse effects on consumers in so far as the eggs were treated with ozone (Kamotani et al., 2010; RodriguezRomo et al., 2005). 


\section{The interaction of ozone with materials}

Materials compatible with ozone have to be resistant to corrosion and they should not reduce the ozone functionality. They have to endure the concentration 1 - 3 ppm of ozone. The ozone-resistant materials are: PTFE (Teflon), PVDF (KYNAR), PVC, and ECTFE (Halar). Materials with good resistance to ozone are stainless steel type 316L and 304L (Green et al., 1999; Pascual et al., 2007).

\section{The hazards and toxicity of ozone}

Certain risks of fire hazards especially when ozone is generate from pure oxygen should be emphasized. Those risks are higher by the event of electrical sparks or sudden changes in air temperature or air pressure. However, when the generation and application of ozone is appropriate the fire hazards are low, nevertheless the caution is needed specially when ozone is produced from pure oxygen (Rice, 2012,).

The toxicity of ozone is a more important criterion for the use in food processing plants. Ozone is a toxic gas and may endeavour the respiratory diseases when inhaled in high concentrations. In nature ozone is the one of the most potential active oxidants, with a strong impact on the animals, plants and living organisms (Iriti et al., 2008). Owing to this it is important to maintain and control low concentrations of ozone in the air. This is very important for people who are working with and come into the contact with ozone. In humans, toxicity of ozone is manifested primarily on the respiratory system (Pryor et al., 1995). The toxicity of ozone varies depending on the concentration and duration of exposure. Headache, dizziness, eyes and throat burning sensations, sharp taste, smell and cough are the symptoms of acute intoxication with ozone. Symptoms of chronic intoxication may include headache, nausea, diminished memory, the increased prevalence of bronchitis and increased muscle excitability (Guzel-Seydim et al., 2004). Ozone at a concentration between 0.1 - 1.0 ppm can cause symptoms including headaches, dry mouth, respiratory and eyes irritation. Exposure of 1.0 - 100 ppm can cause asthma, fatigue and loss of appetite (Pascual et al., 2007) . Short exposure to ozone at high concentrations can cause irritation of throat, bleeding and pulmonary congestion. In the United States the current authorized levels of ozone exposure in the working environment is $0.1 \mathrm{ppm}$ (OSHA) as concentration at which susceptible individuals may be exposed to ozone under normal operating conditions for 8 hours per day, or 40 hours per week, with no adverse effects (Pascual et al., 2007, Rice, 2012). The maximum value of the short-term exposure is $0.3 \mathrm{ppm}$. Short-term exposure is less than 15 min, not more than 4 times a day, at intervals of at least 1 hour between each short-term exposure (Prior and Rice, 2000, cited by Pascual et al., 2007).
Due to this, monitoring of the ozone concentrations in the workplace air is obligatory using sensors for ozone levels monitoring (Tapp and Rice, 2012). Sensors have to be equipped with alarm which turn on when the ozone concentration exceed 0.1 ppm (Figure 3.). Sa-

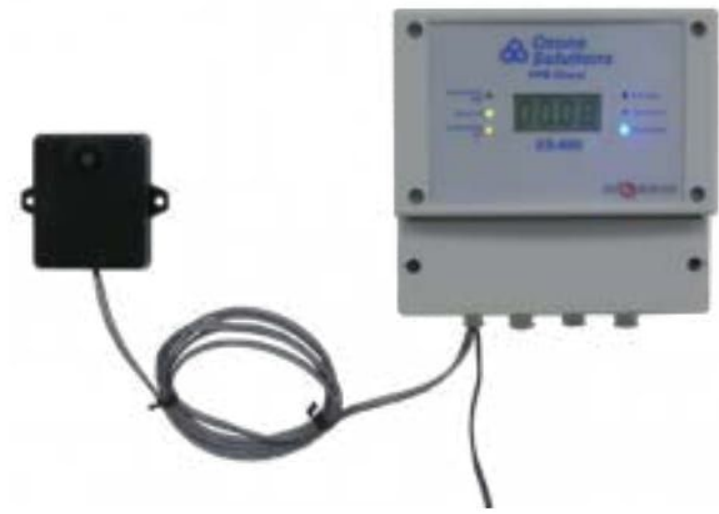

Figure 3 Industrial Ozone Controller with Digital Display (Ozone Solutions, 2017)

fety precautions are neccessary, particularly when ozone is used indoors in gas form. When ozone is used as ozonated water the excessive gaseous ozone has to be neutralised or changed back into oxygen. For this purpose ozone catalysts have to be installed in the generators (Pascual et al., 2007).

\section{CURRENT BIOCIDAL PRODUCTS REGULATION (EU) 528/2012 IN EU}

Ozone is regulated as an "active substance" under the Biocidal Products Regulation (EU) 528/2012 (BPR) (European Ozone Trade Asssociation, 2017). This Regulation is obligatory to everyone who wishes to trade ozone generators for biocidal use in EU. Since ozone is the substance generated in situ, special guidance on the management of in situ generated active substances has to be considered (Mereu and Maldegem, 2015).

In the transitional procedure the approval of ozone as an active substance and biocidal product will have to comply with the envisaged Article 93 of the BPR, after the deadline of 1 September 2017 and in accordance with Member States' national rules. The Article 93 transitional measures are valid only for biocidal products that were available or used on the market on 1 September 2013 (European Chemicals Agency, 2017).

The deadline for the submission of the dossier for the active substance approval was 1 September 2016 for the all market operators making available pure oxygen for the purpose of generating ozone From 1 September 2015, a biocidal product, the substance supplier, or the product supplier has to be included in the Article 95 list for the product type to which the product belongs (European Chemicals Agency, 2017). 
Thus this process required first an "active substance" dossier. Thus for ozone this has to be submitted until September 2016 and thereafter a specific application for each product to be marketed within the EU has to be submitted by September 2017 (Mereu and Maldegem, 2015).

\section{CONCLUSIONS}

Despite the undoubtedly positive effects of ozone and advantages over other chemicals in the food industry there is still not a final decision and consensus on whether ozone can be used as a disinfectant in the food industry in the EU. September 1, 2017 is the date after which it will decide on the fate of the use of ozone for sanitation. Despite some of the risks of the use and moderate toxicity, ozone, when properly applied and under the supervision and monitoring, still remains one of the most effective alternative disinfectants in the food industry.

\section{REFERENCES}

Al-Haddad Khawla, S.H., R.A.S. Al-Qassemi, R.K.Robinson (2005): The use of gaseous ozone and gas packaging to control populations of Salmonella infantis and Pseudomonas aeruginosa on the skin of chicken portions. Food Control 16(5), 405-410.

Anonymous (1983): Process for the synthetic production of ozone by electrolysis and use thereof. US Patent4416747A. https://www.google.com/patents/US4416747 (jun. 2017)

Battino, R., T.R. Rettich, T. Tominaga (1983): The Slubilty of Oxygen and Ozone in liquids. J. Psys. Chem.Ref.Data 12(2), 163-178.

Biocidal Products Regulation (2017): European Ozone Trade Asssociation. http:// www.euota.org/biocidal-products-regulations/ (jun. 2017)

Chang, J.S., P.A. Lawless, T. Yamamoto (1991): Corona Disharge process. leee Transactions On Plasma Science 19(6), 1152-1166.

European Chemicals Agency (2017): Article 93 transitional measure. https://echa. europa.eu/ de/regulations/biocidal-products-regulation/in-situ-generated-active-substances/article-93-transitional-measure (jun. 2017)

European Chemicals Agency (2017a): Official Article 95 list for biocides published https://echa.europa.eu/de/-/official-article-95-list-for-biocides-published (jun. 2017)

European Ozone Trade Asssociation (2017): Biocidal Products Regulation. http:// www.euota.org/biocidal-products-regulations/ (jun. 2017)

Foegeding, P.M. (1985): Ozone inactivation of Bacillus and Clostridium spore populations and the importance of the spore coat to resistance. Food Microbiology 2 (2), 123-134.

Forni, L., D. Bahnemann, E.J. Hart (1982): Mechanism of the Hydroxide lon Initiated Decomposition of Ozone in Aqueous Solution. J. Phys. Chem. 86(2), 255-259.

Foumaud, J., R. Lauret (1972): Influence of ozone on the surface microbial flora of frozen beef during thawing. Ind. Aliment Agric. 89, 585-589.

Gordon G. (1995): The chemistry and reactions of ozone in our environment. Progr. Nuclear Energy 29 (Supl.), 89-96.

Greene, A.K., B. K. Few, C. Joao, Serafini (1993): A comparison of ozonation and chlorination for the disinfection of stainless steel surfaces. Journal of Dairy Science 76, 36173620.

Green, A.K., G.W. Smith, C.S. Knight (1999): Ozone in dairy chilling water systems: effect on metal materials. International Journal of Dairy Technology 52 (4), 126-128.

Green, A.K., Z.B. Guzel-Seydim, A.C. Seydim (2012): Chemical and Physical Properties of Ozone. Ozone in food processing. Edited by $0^{\prime}$ Donnell, C., B.K.T iwari, P.J. Cullen, R.G. Rice
Wiley-Blackwell, $298 \mathrm{p}$

Guzel-Seydim, Z.,P. Jr.B. Bever, A.K. Greene (2004): Efficacy of ozone to reduce bacterial populations in the presence of food. Food Microbiology 21(4), 475-479.

Guzel-Seydim, Z., A.K. Greene, C. Seydim (2004): Use of ozone in the food industry. Lebensm.-Wiss. u.-Technol. 37, 453-460.

Hewes, C.G., R.R. Davison (1971): Kinetics of ozone decomposition and reaction with organics in water. Aiche Journal 17 (1), 141-147.

Iriti, M., F. Faoro (2008): Oxidative Stress, the Paradigm of Ozone Toxicity in Plants and Animals. Water Air Soil Pollut 187 (1), 285-301.

Ipsen,R. (1989): Factors affecting the storage of whole milk powder. Scand. Dairy Ind. 3,24-26.

Kamotani, S., N. Hooker, S. Smith, K. Lee (2010): Consumer acceptance of ozonetreated whole shell eggs. J Food Sci. 75 (2), 103-107.

Kaothien, P., R. Jhala, D. Henning, J. L. Julson, K. Muthukumarappan, R.I. Dave (2001): Effectiveness of ozone for controlling L. monocytogenes in cured ham. Inst. of Food Technolo. Ann. Meeting New Orleans, LA. June, 23-27.

Khadre, M.A., A.E. Yousef, JG. Kim (2001): Microbiological Aspects of Ozone Applications in Food: A Review. Journal Of Food Science 66 (9), 1242-1252.

Khadre, M.A., A.E. Yousef (2001): Sporicidal action of ozone and hydrogen peroxide: a comparative study. International Journal of Food Microbiology 71, 131-138.

Kim, J.G., A.E. Yousef, M.A. Khadre (2003): Ozone and its current and future application in the food Industry. Advances In Food And Nutrition Research 45, 167-218.

Kim, J.G., A.E. Yousef, S. Dave (1999): Application of Ozone for Enhancing the Microbiological Safety and Quality of Foods: A Review. Journal of Food Protection 62 (9), 1071-1087.

Kim, J.G., A.E. Yusef (2000): Inactivation Kinetics of Foodborne Spoilage and Pathogenic Bacteria by Ozone. Journal Of Food Science 65 (3), 521-528.

Korich, D.G., J.R. Mead, M.S. Madore, N.A. Sinclair, C.R. Sterling (1990): Effects of Ozone, Chlorine Dioxide, Chlorine, and Monochloramine on Cryptosporidium parvum Oocyst Viability. Applied And Environmental Microbiology 56 (7), 1423-1428.

Lopez-Galvez, F., G. Posada, V.M. Selma, A. Allende (2012): Electrochemical disinfection: An efficacy treatment to inactivate Escherichia coli 0157:H7 in process wash water containing organic matter. Food Microbiology 30(1), 146-56.

Loretz, M., R. Stephan, C. Zweifel (2010): Antimicrobial activity of decontamination treatments for poultry carcasses: A literature survey. Food Control 21(6), 791-804.

Lukes,P., V. Babicky, V.Janda, P. Sunka (2005): Generation of ozone by pulsed corona discharge over water surface in hybrid gas-liquid electrical discharge reactor. Journal of Physics D Applied Physics 38 (3), 409-416.

Mahapatra, A K., K. Muthukumarappan, J.L. Julson (2005): Applications of Ozone, Bacteriocins and Irradiation in Food Processing: A Review. Journal Critical Reviews in Food Science and Nutrition 45 (6), 447-461.

Martinez-Huitle, C.A., S. Ferro (2006): Electrochemical Oxidation of Organic Pollutants for the Wastewater Treatment: Direct and Indirect Processes. Chemical Society Reviews 35 (12), 1324-40.

Mereu, C., K. Maldegem (2015): In situ guidance under the BPR and the case of ozone. Fieldfisher 2015. http://www.fieldfisher.com/publications/2015/07/in-situ-guidance-underthe-bpr-and-the-case-of-ozone\#sthash.NKnbsdUM.CpizTZpG.dpbs (jun. 2017)

Moore, G., C.J. Griffith (2000): Bactericidal Properties of Ozone and Its Potential Application as a Terminal Disinfectant. Journal of Food Protection 63(8), 1100-1106.

Mustafa, M.G. (1990): Biochemical basis of ozone toxicity. Free Radical Biology and Medicine, 9. 245-65.

Muthukumarappan, K.,F. Halaweish, A.S. Naidu (2000): “Ozone". In Natural Food Anti-Microbial Systems. Edited by: Naidu, A. S. Boca Raton, FL: CRC Press, 783-800.

O'Donnell, C., B.K. Tiwari, PJ. Cullen, R.G. Rice (2012): Status and Trends of Ozone 


\section{Scientific and professional section}

in Food Processing. Ozone in food processing. Edited by O'Donnell, C., B.K. Tiwari, P.J. Cullen, R.G. Rice Wiley-Blackwell, $298 \mathrm{p}$

Olmez, H., U.Kretzschmar (2009): Potential alternative disinfection methods for organic fresh-cut industry for minimizing water consumption and environmental impact. LWT - Food Science and Technology 42(3), 686-693.

Pascual A, I. Llorca, A. Canut (2007): Use of ozone in food industries for reducing the environmental impact of cleaning and disinfection activities. Trends in Food Science \& Techno$\log y$ 18, 29-35.

Peeters, J.E., E.A. Mazas, W.J. Masschelein, I.V. Martinez de Maturana, E. Debacker (1989): Effect of Disinfection of Drinking Water with Ozone or Chlorine Dioxide on Survival of Cryptosporidium parvum 0ocysts. Applied And Environmental Microbioiogy 55 (6), 1519-152.

Pehkonen, A. (2001): The effect of dissolved ozone on the corrosion behavior of some stainless steels, Dissertation, Helsinki University of Technology, Department of Materials Science and Rock Engineering, $117 \mathrm{p}$.

Pekarek, S. (2003): Non-Thermal Plasma Ozone Generation. Acta Polytechnica 43 (6), 47-51. https://ojs.cvut.cz/0js/index.php/ap/article/viewFile/498/330, http://onlinelibrary. wiley.com/doi/10.1111/j.1365-2672.2008.04141.x/full (jun. 2017)

Pirani, S. (2010): Application of ozone in food industries. Doctoral Program in Animal Nutrition and Food Safety. Doctoral Program in Animal Nutrition and Food Safety. Università degli Studi di Milano, 127 p. https://air.unimi.it/retrieve/handle/2434/153539/133108/phd unimi_R07 489.pdf(jun. 2017)

Portjanskaja, E. (2006): Ozone Reactions With Inorganic And Organic Compounds In Water. UNESCO - Eolss, Sample Chapters, 9 p. http://www.eolss.net/sample-chapters/c07/ e6-192-06-00.pdf (jun. 2017)

Potts, H.E., D.A. Diver, P.C. Everest, R.D. O'Connor (2011): Plasma decontamination of sealed packages. 30th ICPIG, August 28th - September 2nd 2011, Belfast, UK, Topic No. 16 http://www.anacail.com/wp-content/uploads/Anacail_plasma-decontamination.pdf (jun. 2017)

Pryor, W., G.L. Squadrito, M. Friedman (1995): The Cascade Mechanism To Explain Ozone Toxicity: The Role Of Lipid Ozonation Products. Free Radical Biology \& Medicine 19(6), 935-941.

Restaino, L., E.W. Frampton, J.B. Hemphill, P. Palnikar (1995): Efficacy of Ozonated Water against Various Food-Related Microorganisms. Applied And Environmental Microbiology 61 (9), 3471-3475.

Rice, R.G. (1986): Application of ozone in water and wastewater treatment. In Rice, R.G., Bollyky L.J. and Lacy, W.J. (eds) Analytical Aspects of Ozone Treatment of Water and Wastewater, Chelsea, Ml: Lewis Publishers, 7-26.

Rice, R.G. (2012): Health and Safety Aspects of Ozone Processing. Ozone in food processing. Edited by O'Donnell, C., B.K. Tiwari, P.J. Cullen, R.G. Rice Wiley-Blackwell, $298 \mathrm{p}$
Rice, R.G., D.M. Graham, M.T. Lowe (2002): Recent 0zone Applications in Food Processing and Sanitation. Food Safety Magazine October/November. http://www.foodsafetymagazine. com/magazine-archive1/octobernovember-2002/recent-ozone-applications-in-foodprocessing-and-sanitation/ (jun. 2017)

Rodriguez-Romo, L.A., A.E.Yousef (2005): Inactivation of Salmonella enterica Serovar Enteritidis on Shell Eggs by Ozone and UV Radiation. Journal of Food Protection 68 (4), 711-717.

Roth, J.A., D.E. Sullivan (1981): Solubility of ozone in water. Eng. Chem. Fundamen $20(2), 137-140$

Sehested, K., H. Corfitzen, J. Holcman, EJ. Hart(1992): Decomposition of ozone in aqueous acetic acid solutions (pH 0-4). J. Phys. Chem. 96 (2), 1005-1009.

Sheldon, B.W., A.L. Brown (1986): Efficacy of Ozone as a Disinfectant for Poultry Carcasses and Chill Water. J.of Food Sci. 51 (2), 305-309.

Staehelin, J., J.Hoigne (1982): Decomposition of ozone in water: rate of initiation by hydroxide ions and hydrogen peroxide. Environ. Sci. Technol. 16 (10), 676-681.

Šimek, M., S. Pekarek,V. Prukner (2012): Ozone Production Using a Power Modulated Surface Dielectric Barrier Discharge in Dry Synthetic Air. Plasma Chemistry and Plasma Processing 32(4), 743-754.

Tapp, C., R.G.Rice (2012): Generation and Control of Ozone. Ozone in food processing. Edited by O'Donnell,C.,B.K.Tiwari,P..Cullen,R.G.Rice Wiley-Blackwell, 298 p

Victorin, K. (1992): Review of the genotoxicity of ozone, Mutation Research 277, 221-38.

Wei, K., Hongde Zhou,Ting Zhou, Jianhua Gong (2007): Comparison of Aqueous Ozone and Chlorine as Sanitizers in the Food Processing Industry: Impact on Fresh Agricultural Produce Quality. The Journal of the International Ozone Association Volume 29 (2), 113-120.

Weschler, C.J. (2000): Ozone in Indoor Environments: Concentration and Chemistry. Indoor Air 10, 269-288.

Wysok, B., J. Uradziński, M. Gomółka-Pawlicka (2006): Ozone as an alternative disinfectant - a review. Pol. J. Food Nutr. Sci. 15 (56), 3-8.

Yang, P.P.W., T.C.Chen (1979): Stability of ozone and its germicidal properties on poultry meat microorganisms in liquid phase. J. Food Sci. 44, 501-504.

Yousef, A.E., M. Vurma, L.A. Rodriguez-Romo (2011): Basics Of Ozone Sanitation And Food Applications. Nonthermal Processing Technologies for Food. Wiley - Blackwell, 291293.

Young, S.B., P.Setlow (2004): Mechanisms of Bacillus subtilis spore resistance to and killing by aqueous ozone. Journal of Applied Microbiology 9 (5), 1133-1142.

Yuceer, M., M.S. Aday, C. Caner (2016): Ozone Treatment of shell eggs to preserve functional quality and enchance shelf life during storag. J Sci Food Agric. 96(8), 2755-2763.

Delivered: 19.6.2017.

Accepted: 8.7.2017.

\section{Ozon kao alternativni dezinficijens u prehrambenoj industriji}

\section{SAŽETAK}

U prehrambenoj industriji dezinficijensi trebaju osigurati kvalitetu i mikrobiološku sigurnost hrane bez rizika za ljudsko zdravlje ili okoliš. Jedan od mogućih alternativnih i manje toksičnih dezinficijensa je ozon. Ozon je vrlo učinkovit dezinficijens i ekološki prihvatljiv na mnogim mjestima proizvodnje hrane, npr. na opremi i direktno na prehrambenim proizvodima.

Ključne riječi: ozon, prehrambena industrija, sanitacija, dezinfekcija 


\section{Ozon als alternatives Desinfektionsmittel in der Lebensmittelindustrie}

\section{ZUSAMMENFASSUNG}

Die Aufgabe eines Desinfektionsmittels in der Lebensmittelindustrie besteht darin, die Qualität und mikrobiologische Sicherheit der Nahrung ohne Risiken für die menschliche Gesundheit und Umwelt sicherzustellen. Ozon zählt zu alternativen, weniger toxischen Desinfektionsmitteln. Es gilt als sehr effektiv, zeichnet sich durch eine geringe Toxizität aus und eignet sich ökologisch für zahlreiche Bereiche wie zum Beispiel offene (Reinigung offener Flächen) und geschlossene Flächen (Reinigung geschlossener Flächen), für Zubehör, unmittelbar an Lebensmitteln bei der Wasserdesinfizierung, für die Beseitigung von Gerüchen und Neutralisierung von Pestiziden.

Schlüsselwörter: Ozon, Lebensmittelindustrie, Hygiene, Desinfektion

\section{Ozono como desinfectante alternativo en la industria alimentaria}

\section{RESUMEN}

En la industria alimentaria los desinfectantes deben asegurar la calidad y la seguridad microbiológica de la comida sin el riesgo para la salud humana y para el medio ambiente. El ozono es una de las posibles soluciónes alternativas y un desinfectante menos tóxico. El ozono es un desinfectante muy eficaz, de la toxicidad baja y ecológicamente aceptable en muchos campos como las superficies abiertas (saneamiento COP) e interiores (saneamiento CIP) del equipo, directamente en los productos alimenticios durante el saneamiento del agua, en la eliminación del olor y en la neutralización de los pesticidas.

Palabras claves: ozono, industria alimentaria, saneamiento, desinfección

\section{L’ozono come disinfettante alternativo nell'industria alimentare}

\section{SUNTO}

Nell'industria alimentare i disinfettanti devono garantire la qualità e la sicurezza microbiologica dei cibi senza alcun rischio per la salute umana e per l'ambiente. Uno dei disinfettanti alternativi e meno tossici è senz'altro l'ozono. L'ozono è un disinfettante molto efficace con un basso grado di tossicità e un basso impatto ecologico. Ė utilizzabile non solo sulle superfici aperte (trattamento igienico-sanitario delle superfici aperte COP) e sulle superficichiuse (trattamento igienico-sanitario delle superfici chiuse CIP), ma anche sull'attrezzatura, direttamente sui prodottialimentari, nel trattamento igienico-sanitario dell'acqua, nell'eliminazione dei cattivi odori e nella neutralizzazione dei pesticidi.

Parole chiave: ozono, industria alimentare, trattamento igienico-sanitario, disinfezione

\section{9th Meat Industry Conference, Mt. Zlatibor, Serbia on October 1-4, 2017.}

We are pleased to invite you to participate in the International 59th Meat Industry Conference to be held in Hotel "Mona" Mt. Zlatibor, Serbia on October 1-4, 2017.

- Meat Industry Conference has been traditionally organized by the Institute of Meat Hygiene and Technology from Belgrade (Serbia) and represents unique event in our country where numerous experts, researchers and meat industry employees exchange experience and ideas aiming to present new scientific and technological achievements in meat hygiene and technology. The Conference has always been oriented toward actual problems in meat industry, so we have selected the topic of the Conference to be BETTER FOOD-BETTER LIFE. Scientific Programme includes lectures given by invited international and domestic experts which will be published in the "IOP Proceedings: Earth and Environmental Sciences" along with papers presented within sessions.

- We encourage you to join us at Mt. Zlatibor hoping you will enjoy your stay here and that you will find acquired knowledge to be useful.

CHAIRMAN OF THE PROGRAMME COMMITTEE

Branko Velebit, DVM, Ph.D.

http://meatcon2017.co.rs/ 